\title{
The Roles of Moonlighting Proteins in Bacteria
}

\author{
Guangqiang Wang ${ }^{1}, \mathrm{Yu} \mathrm{Xia}^{2}$, Jing Cui ${ }^{1,2}$, Zhennan $\mathrm{Gu}^{2}$, \\ Yuanda Song ${ }^{2}$, Yong Q. Chen ${ }^{2}$, Haiqin Chen ${ }^{2 *}$, Hao \\ Zhang $^{2}$ and Wei Chen ${ }^{1 *}$ \\ ${ }^{1}$ State Key Laboratory of Food Science and Technology, \\ Jiangnan University, Wuxi 214122, P.R. China \\ ${ }^{2}$ School of Food Science and Technology, Jiangnan \\ University, Wuxi 214122, P.R. China
}

\begin{abstract}
Moonlighting proteins, characterized by their multiple autonomous functions, have been detected in bacteria. Surprisingly, many of these proteins are conserved and involved in metabolic pathway or the cell stress response. They localise to the bacterial surface to take on additional activities, which have been hypothesised to contribute to bacterial virulence or bacterial benefit. In this review, we compare the functions of moonlighting proteins in bacteria, describe the structural basis of moonlighting functions, and summarise the regulation of secretion and localisation of moonlighting proteins.
\end{abstract}

\section{Introduction}

Almost 20 years ago, it was reported that certain neuropeptides displayed immunomodulatory activity along with their classic neuropeptide function (Campbell and Scanes, 1995). The term "moonlighting protein" was introduced to describe a single protein that has multiple functions not due to gene fusions, splice variants or multiple proteolytic fragments (Jeffery, 2009; Huberts and van der Klei, 2010). Since their initial discovery, a significant number of proteins have been found to serve two or more functions in plants, animals, yeast and prokaryotes. Most of the moonlighting proteins in bacteria have been primarily identified as glycolytic enzymes, other metabolic enzymes, or molecular chaperones. They localise to the bacterial surface to take on additional activities. Because their sequences contain neither known sequence motifs for surface anchoring nor identified secretion signals, bacterial moonlighting proteins were originally described as being "anchorless proteins" or "non-classically secreted proteins" (Pancholi and Chhatwal, 2003). These proteins have been found on many pathogens surfaces, and they have been considered to be involved with the pathogenic process (Pancholi and Chhatwal, 2003; Henderson and Martin, 2011). Major identified moonlighting functions include adhesion to host epithelia, host components, such as extracellular matrices (ECMs) and plasminogen, and the modulation of host immune responses (Pancholi and Fischetti, 1992; Seifert et al., 2003; Carneiro et al., 2004; Burnham et al., 2005; Blau et al., 2007; Xolalpa et al., 2007). While many studies have suggested that moonlighting protein functions contribute to bacterial virulence, few have provided direct

*Corresponding author: haiqinchen@jiangnan.edu.cn, chenwei66@jiangnan.edu.cn evidence for the role of cell surface proteins in bacterial virulence (Madureira et al., 2007; Jin et al., 2011). Recently, research has focused on the roles of moonlighting proteins in probiotics. Surprisingly, many moonlighting proteins identified in the probiotics have similar functions within the pathogenesis (Kelly et al., 2005; Antikainen et al., 2007a; Sánchez et al., 2008). Additionally, many of the moonlighting proteins in pathogens and probiotics are highly conserved proteins. Given the rapidly expanding number of moonlighting proteins, this review is not an attempt to comprehensively summarise moonlighting proteins or their multiple functions in different Gram-positive bacteria. Rather we take a broad view, outlining the roles of major moonlighting proteins (Table 1), comparing the functions of moonlighting proteins in different bacteria, generalising the structural basis of moonlighting functions, and summarising the regulations of secretion and localisation of moonlighting proteins.

\section{Roles of moonlighting proteins in bacteria}

\section{Adhesion}

Moonlighting proteins localise to the bacterial surface and an increasing number of scientific reports ascribe their adhesion activities to components of the intestinal mucosa. Many researchers have proposed that the adhesive activity of moonlighting proteins is important to bacterial adhesion and colonisation, which are important for the physiology of bacteria.

It has been shown that many moonlighting proteins are able to bind to host epithelial components, like mucus or ECM components, or directly adhere to epithelial cell lines in pathogens. Glyceraldehyde-3-phosphate dehydrogenase (GAPDH) is a particularly well-known example of a protein with this adhesion ability.

GroupA streptococci (Streptococcus pyogenes) GAPDH is one of the earliest examined moonlighting proteins. Pancholi and Fischetti (1992) first identified GAPDH as the major surface protein for group A type streptococci and designated it as streptococcal surface GAPDH (SDH). The protein was shown to bind to fibronectin, lysozyme, the cytoskeletal proteins myosin and actin (Pancholi and Fischetti, 1992; Winram et al., 1996; D'Costa et al., 2000; Jin et al., 2005). GAPDH has also been shown to bind to mucin in the species Mycoplasma pneumoniae (Alvarez et al., 2003), and to fibrinogen and colon epithelial Caco-2 cells in enterohemorrhagic (EHEC) and enteropathogenic (EPEC) Escherichia coli strains (Egea et al., 2007, Aguilera et al., 2009). However, GAPDH is not the only known protein able to bind to epithelial components. Enolase from Staphylococcus aureus was shown to bind to laminin and collagen I, but not to fibronectin and collagen IV (Antikainen et al., 2007a), and enolase from Streptococcus mutans was found to bind to human plasminogen and salivary mucin MG2 (Ge et al., 2004). Other examples are fructose1,6-bisphosphate aldolase (FbaA) from Streptococcus pneumoniae (Blu et al., 2007), phosphoglycerate kinase (Pgk) of Streptococcus agalactiae (Burnham et al., 2005), 
Table 1. Moonlighting functions of non-classically secreted proteins.

\begin{tabular}{|c|c|c|c|}
\hline Bacteria & Proteins & Moonlighting activity & Reference (s) \\
\hline \multirow[t]{2}{*}{$\begin{array}{l}\text { S. pyogenes also known as } \\
\text { group Astreptococcus }\end{array}$} & GAPDH & $\begin{array}{l}\text { Binding to plasmin(ogen), } \\
\text { fibronectin, lysozyme, myosin and } \\
\text { actin; recognizes uPAR/CD87 as its } \\
\text { receptor; C5a-binding protein }\end{array}$ & $\begin{array}{l}\text { Winram et al., 1996; D'Costa et al., 2000; } \\
\text { Pancholi and Fischetti, 1992; Jin et al., } \\
\text { 2005; Terao et al., } 2006\end{array}$ \\
\hline & Enolase & The strongest binder of plasminogen & Pancholi and Fischetti, 1998 \\
\hline S. aureus & Enolase & Laminin binding protein & Carneiro et al., 2004 \\
\hline \multirow[t]{3}{*}{ S. pneumoniae } & GAPDH/Enolase & Plasmin(ogen) binding proteins & $\begin{array}{l}\text { Bergmann et al., 2004; Eberhard et al., } \\
1999\end{array}$ \\
\hline & $\begin{array}{l}17 \text { glycolytic } \\
\text { enzymes }\end{array}$ & $\begin{array}{l}\text { Antigenic and eliciting protective } \\
\text { immune reponses in mouse }\end{array}$ & Ling et al., 2004 \\
\hline & FbaA & $\begin{array}{l}\text { As a lectin binding to host cadherin } \\
\text { receptor termed flamingo }\end{array}$ & Blau et al., 2007 \\
\hline \multirow[t]{2}{*}{$\begin{array}{l}\text { S. agalactiae also known as } \\
\text { Group B streptococcus }\end{array}$} & GAPDH & $\begin{array}{l}\text { Bind plasminogen, actin and } \\
\text { fibrinogen, B lymphocyte stimulatory } \\
\text { activity }\end{array}$ & Seifert et al., 2003; Madureira et al., 2007 \\
\hline & Pgk & Binds to cellular actin & Burnham et al., 2005 \\
\hline S. mutans & Eno & $\begin{array}{l}\text { Binds to mucin MG2 and } \\
\text { plasminogen }\end{array}$ & Ge et al. 2004 \\
\hline \multirow[t]{2}{*}{ M. pneumoniae } & EF-Tu, PdhB & Fibronectin binding protein & Dallo et al., 2002 \\
\hline & GAPDH & Adhesin for mucin & Alvarez et al., 2003 \\
\hline \multirow[t]{3}{*}{ M. tuberculosis } & malate synthase & Laminin-binding adhesin & Kinhikar et al., 2006 \\
\hline & SodA & $\begin{array}{l}\text { Binding to different epithelial cell } \\
\text { proteins }\end{array}$ & Reddy and Suleman, 2004 \\
\hline & DnaK & Plasminogen binding protein & Xolalpa et al., 2007 \\
\hline B. anthracis & GAPDH/Enolase & Plasminogen binding protein & Matta et al., 2010; Agarwal et al., 2008 \\
\hline EHEC and EPEC & GAPDH & $\begin{array}{l}\text { Bind plasminogen, fibrinogen and } \\
\text { colon epithelial Caco- } 2 \text { cells; NAD- } \\
\text { ribosylating activity }\end{array}$ & Egea L et al., 2007; Aguilera et al., 2009 \\
\hline L. jensenii & Enolase & Inhibitor of Neisseria binding & Spurbeck and Arvidson, 2010 \\
\hline \multirow[t]{2}{*}{ L. johnsonii } & EF-Tu & $\begin{array}{l}\text { Binding to intestinal cells and } \\
\text { to mucins and inducing a } \\
\text { proinflammatory }\end{array}$ & Granato et al., 2004 \\
\hline & GroEL & $\begin{array}{l}\text { Bind to mucins and human intestinal } \\
\text { epithelial cells; immunomodulatory } \\
\text { effects and mediates the } \\
\text { aggregation of the gastric pathogen } \\
\text { H. pylori }\end{array}$ & Bergonzelli et al., 2006 \\
\hline L. fermentum & Tig & $\begin{array}{l}\text { Anti-adhesive of Enterococcus } \\
\text { faecalis } 1131\end{array}$ & Heinemann et al., 2006 \\
\hline \multirow[t]{3}{*}{ L. plantarum } & GAPDH & $\begin{array}{l}\text { Adheres to mucin and } \\
\text { fibronectin,adhesion of Caco- } 2 \text { cells }\end{array}$ & Kinoshita et al., 2008; Ramiah et al. 2008 \\
\hline & Enolase & Fibronectin binding protein & Castaldo et al., 2009 \\
\hline & EF-Tu, TPI & $\begin{array}{l}\text { Contribution to adhesion of Caco-2 } \\
\text { and competitive exclusion of the } \\
\text { other strains }\end{array}$ & Ramiah et al., 2008 \\
\hline \multirow[t]{3}{*}{ L. crispatus } & GAPDH/Enolase & $\begin{array}{l}\text { Binding plasminogen and enhanced } \\
\text { its activation }\end{array}$ & Hurmalainen et al., 2007 \\
\hline & EF-Tu & Adhesion & Siciliano et al., 2008 \\
\hline & GS & $\begin{array}{l}\text { Adhesion, binds to type I } \\
\text { collagen, laminin, fibronectin and } \\
\text { plasminogen. }\end{array}$ & Kainulainen et al., 2012 \\
\hline
\end{tabular}


malate synthase of Mycobacterium tuberculosis (Kinhikar et al., 2006), and elongation factor Tu (EF-Tu) and E1 b subunit of pyruvate dehydrogenase (PdhB) from $M$. pneumoniae (Dallo et al., 2002). In addition, superoxide dismutase has been shown to bind with HEp-2 and A549 cells, and to adhere to aldolase, GAPDH and cyclophilin A inside epithelial cells (Reddy and Suleman, 2004). It is generally thought that by binding to host components these surface-located proteins help pathogens to adhere to host cells, and facilitate their colonisation and subsequent invasion. However, because these moonlighting proteins play important roles within the cells, it makes the creation of a knockout mutant impossible. Thus, only a few studies have provided direct experimental evidence to support the hypothesis of the importance of moonlighting proteins for bacteria virulence. One of the most elegant and direct pieces of evidence in this regard was that provided by Boël et al. (2005), who created a novel GAS mutant strain expressing $\mathrm{SDH}$ with a 12-amino-acid hydrophobic tail at its C-terminal end, which was able to prevent its surface exportation without altering its enzymatic activity and the growth pattern of the bacteria. The GAPDH mutant adhered poorly to human pharyngeal cells, bound significantly less with human plasminogen, and lost its innate antiphagocytic activity (Boël et al., 2005). More importantly, the mutant was completely attenuated for virulence in a mouse peritonitis model (Jin et al., 2011). This result was the first to demonstrate that SDH plays an important role in GAS adherence to pharyngeal cells and is thus necessary for bacteria virulence.

Surprisingly, moonlighting proteins in commensal bacteria have roles similar to those of pathogens in adhesion. They also bind to host epithelial components or adhering directly to epithelial cell lines. Similar to S. pyogenes, cell surface GAPDH from Lactobacillus plantarum has been shown to bind to mucin and fibronectin (Kinoshita et al., 2008). It can also adhere directly to Caco-2 cells (Ramiah et al., 2008). Furthermore, GAPDH is not the only protein with adhesion ability. Similar to $S$. aureus, enolase from Lactobacillus crispatus can also bind to laminin and collagen I, but not to fibronectin and collagen IV (Antikainen et al., 2007a). Enolase from L. plantarum has been reported to bind to fibronectin (Castaldo et al., 2009). EF-Tu and glutamine synthetase (GS) involved in the adhesion of $L$. crispatus (Siciliano et al., 2008; Kainulainen et al., 2012), and GS has been found to bind to type I collagen, laminin and fibronectin (Kainulainen et al., 2012). In addition, GroEL and EF-Tu from Lactobacillus johnsonii, and EF-Tu, GAPDH and TPI from $L$. plantarum can directly adhere to epithelial cells. It has been proposed that these moonlighting proteins contribute to some probiotic traits. For instance, some can inhibit the adhesion of pathogens. Enolase of Lactobacillus jensenii inhibits the pathogen Neisseria gonorrhoeae's adherence to epithelial cells (Spurbeck and Arvidson, 2010). Similarly, the trigger factor protein (Tig) from Lactobacillus fermentum inhibits the adhesion of Enterococcus faecalis (Heinemann et al., 2006).

Other research has found that EF-Tu, GAPDH and triosephosphate isomerase (TPI) from $L$. plantarum contribute to the adhesion of Caco-2 cells, and the competitive exclusion and displacement of Clostridium sporogenes and Enterococcus faecalis (Ramiah et al., 2008). The removal of these proteins from the surface of L. plantarum reduced its adhesion to Caco-2 cells and partially excluded adhesion to Clostridium sporogenes and Enterococcus faecalis (Ramiah et al., 2008).

The normal anti-pathogen adhesive activity of probiotics is often unpredictable and depends on the strains used. Furthermore, the inhibition and displacement of pathogens is effected not only by the overall adhesion but also by the type of molecules involved in the adhesion (Collado et al., 2005; Gueimonde et al., 2007). It is likely that selected probiotic strains compete with pathogens for the same receptors of molecules involved in the adhesion in the gut. This hypothesis was supported by a recent experiment using Listeria adhesion protein (LAP). LAP is an alcohol acetaldehyde dehydrogenase (Imo 1634), a housekeeping enzyme, but it can also be present on the surface of Listeria monocytogenes and plays an important role in adhesion and colonisation (Jaqadeesan et al., 2010). Wild type Lactobacillus paracasei showed strong adhesion to Caco-2 cells but none effectively prevented L. monocytogenes infection. In contrast, LAP-expressing recombinant probiotic $L$. paracasei blocked the adhesion, invasion, and translocation of $L$. monocytogenes by interacting with the host cell receptors, thereby protecting the cells from infection (Koo et al., 2012). Because the recombinant probiotics expressed the adhesion proteins of pathogens, they efficiently inhibited the attachment of specific pathogens to the host. These insights could be developed into a new strategy to prevent and exclude specific pathogens. Although there are no reports of the moonlighting proteins from pathogens inhibiting the adhesion of probiotics, it is likely that they would interact and competitively exclude each other. Altogether, these results show that moonlighting proteins from Gram-positive bacterial pathogens and commensal lactobacilli share functional similarity in adhesion.

\section{Plasminogen-binding}

Plasminogen is a proenzyme of the serine protease plasmin that plays a crucial role in fibrinolysis (Lähteenmäki et al., 2005). Conversion of plasminogen (Plg) to plasmin results from a single proteolytic cut by human Plg activators, tissue-type Plg activator (tPA) and urokinase (uPA). The binding of Plg onto bacterial and mammalian cells or tissue surfaces is mediated by its lysine-binding kringle domains and is thus sensitive to lysine and its analogs. Binding to lysines alters the conformation of the Plg molecule so that it is more susceptible to activation by human Plg activators. The interaction of bacteria with host plasminogen and its subsequent activation to plasmin represents a highly successful mechanism for tissue invasion and dissemination (Eberhard et al., 1999; Terao et al., 2006).

GAPDH and enolase from different bacteria have been shown to bind to Plg (Table 1). DnaK from M. tuberculosis and GS of $L$. crispatus can also bind to Plg (Xolalpa et al., 2007; Kainulainen et al., 2012). GAPDH and enolase are the predominant binders of Plg. They have been reported to bind to human Plg with a great affinity in $S$. pyogenes (Winram et al., 1996; Pancholi and Fishchetti, 1998), S. pneumoniae (Bergmann et al., 2004), S. agalactiae and Bacillus anthracis (Agarwal et al. 2008; Matta et al., 2010), enhancing the formation of proteolytic plasmin activity. This has been proposed as another strategy that enhances the virulence of these pathogens due to their interaction with the plasminogen system, which promotes damage 
of extracellular matrices as well as bacterial spread and organ invasion during infection. Direct evidence of the role of enolase on bacteria virulence by binding to plasminogen was confirmed by Bergmann et al. (2003). Pneumococcal mutants expressing enolase with amino acid substitutions in the internal binding motif showed a substantially reduced plasminogen-binding activity and the virulence of these mutants was also attenuated in a mouse model of intranasal infection (Bergmann et al., 2003). This indicates the significance of enolase as the plasminogen binder in the pathogenesis of pneumococcal diseases.

Recently, it was reported that $L$. crispatus and other commensal species efficiently enhanced tPA-mediated Plg activation (Antikainen et al., 2007b; Hurmalainen et al., 2007). Notably, this activity was attributed to major components of the extracellular proteome of $L$. crispatus ST1, enolase and GAPDH (Hurmalainen et al., 2007). It has been suggested that these proteins contribute to the health-promoting effects of lactobacilli in humans by Plg binding and the enhancement of its activation. Interestingly, Antikainen et al (2007b) found that enolases from $L$. crispatus and $L$. johnsonii as well as from $S$. aureus were equally efficient in Plg binding and enhancement of its activation by TPA and UPA. The similarity of Plg-binding proteins and the efficient enhancement of Plg activation by probiotics and pathogens may indicate that they also have similar mechanisms for colonisation and dissemination, and that probiotic bacteria may mimic pathogens in order to survival in the gastrointestinal tract.

\section{Modulation of host immune responses}

Seventeen glycolytic enzymes associated with the cell surface of $S$. pneumoniae are antigenic in children and adults, of which 13 showed an increasing antibody response with age in each of the eight children analysed. Two immunogenic proteins, FbaA and GAPDH have been found to elicit cross-strain protective immunity in mice and conferred protection to respiratory challenges from virulent pneumococci (Ling et al., 2004). In another study, GAPDH from $S$. agalactiae elicited B cell responses. A S. agalactiae strain overexpressing GAPDH showed increased virulence compared with the wild-type strain in C57BL/6 mice, and this virulence was markedly reduced in $\mathrm{IL}-10$-deficient and anti-rGAPDH antiserum-treated mice (Madureira et al., 2007). These results showed that $S$. agalactiae GAPDH is a virulence-associated immunomodulatory protein and can facilitate microbial colonization. Enolase has also been reported as antigen (Pancholi and Fischetti, 1998). However, because the sequence of enolase is highly conserved from archaebacteria to mammals, many studies have found high levels of enolase-reacting autoantibodies in mammals (Pancholi and Chhatwal, 2003). Some studies have also showed that the enolases from pathogens are related to rheumatic heart disease (Fontan et al., 2000) and rheumatoid arthritis (Lundberg et al., 2010).

Other research has shown that EF-Tu is responsible for the selection and binding of the cognate aminoacyl-tRNA to the acceptor site of the ribosome (Nilsson and Nissen, 2005). Despite being a cytoplasmic protein, EF-Tu is also present on the surface of commensal bacteria and is described as a common antigen (Nakamura et al., 1997). The recombinant EF-Tu from $L$. johnsonii can induce the release of IL-8 from HT29 cells in the presence of soluble CD14 (Granato et al.,
2004). As with EF-Tu, it has been found that the heat shock protein GroEL from different Gram-positive bacteria (such as L. johnsonii, Lactococcus lactis and Bacillus subtilis) also is able to stimulate IL- 8 release by HT29 cells in the presence of soluble CD 14 (Bergonzelli et al., 2006). These results suggest that moonlighting proteins could participate in gut homeostasis. Although the moonlighting proteins from pathogen and probiotics can elicit host immune responses, it seems that the proteins involved and the degree of immune responsiveness are different. To date, there are no reports of GAPDH and enolase from commensal bacteria acting as an antigen, although GAPDH and enolase are the common antigens of pathogens. The molecular mechanisms by which released proteins of probiotic bacteria could participate in GIT homeostasis are still unclear, however, the low immune responses of the intestinal mucosa toward intestinal microbiota, especially the anti-inflammatory response to surfaced proteins of probiotic bacteria, have been clearly demonstrated (Ma et al., 2004; Cario and Podolsky, 2006; Sánchez et al., 2008).

It seems that probiotic bacteria may act as 'vaccinum' to contributing some of their health benefits by eliciting host immune responses in a form of attenuated virulence.

\section{Structural basis for moonlighting proteins}

Although there are a multitude of reports on the many multifunctions of moonlighting proteins, few investigate the structural basis for these functions. Enolase is one example of a common Plg binder. It has been reported that the C-terminal lysines form active epitopes in the enolases of S. pneumoniae (Bergmann et al., 2001) and S. pyogenes (Derbise et al., 2004). Bergmann et al. (2003; 2005) identified another novel internal Plg-binding site of enolase from S. pneumoniae. By investigating the protein-protein interaction, a peptide of nine amino acids ${ }^{248}$ FYDKERKVY was identified as the minimal second binding epitope mediating the binding of plasminogen to enolase (Bergmann et al., 2003). The nine residue plasminogen-binding motif is exposed on the octamer enolase surface (Ehinger et al., 2004) and is the key cofactor for plasmin-mediated pneumococcal degradation and transmigration through host ECM (Bergmann et al., 2005). Furthermore, Using site-directed mutagenesis followed by in silico modelling and ion mobility mass spectrometry validation, Cork et al. (2009) revealed that the plasminogen-binding motif residues Lys252 and Lys255, and the C-terminal Lys434 and Lys 435 residues located in the enolase of $S$. pyogenes play an important role in the binding of human plasminogen. Similarly, two different binding sites with fibronectin were found in the 179-amino-acid region spanning the carboxyl terminus of M. pneumoniae EF-Tu (Balasubramanian et al., 2008).

Although enloases from L. crispatus and L. johnsonii are high efficient in Plg binding, the C-terminal lysines were not present in these sequences (Antikainen et al., 2007a). Further analyses have found that a related second plasminogen-binding sequence ${ }^{248} \mathrm{FYNKDDHKY}$ is present in $L$. crispatus enolase, but substitution of the two lysines in this sequence has little effect on Plg activation (Antikainen et al., 2007a). It has been shown that the arginine and histidine residues of plasminogen-binding M-like proteins and the PAM related protein Prp are involved the binding of Plg (Sanderson-Smith et al., 2006; 2007), however, more 
research is needed to confirm whether these amino acids in the lactobacillar enolase are related to the binding of Plg. Currently, a large number of 3D structures of moonlighting proteins have been identified, however most of these concern their structure and primary function. Few studies have analysed their structural and moonlighting functions. Although Khan et al. (2012) evaluated the performances of the protein function prediction, the extended similarity group and PSI-BLAST in predicting the functional diversity of moonlighting proteins, there is no data on the structural basis of moonlighting proteins that are able to induce host immune responses and bind to components of the intestinal mucosa. Further research is necessary in order to evaluate the structure and functions of moonlighting proteins.

\section{Regulations of secretion and localisation of moonlighting proteins}

Moonlighting proteins also play important intracellular functions, so the secretion of these proteins is tightly regulated and is usually induced by specific stimuli. Signal peptide-independent transport may be the most important strategy to protect cells from the undesirable effects of these moonlighting proteins. In contrast to exported proteins with signal peptide, these moonlighting proteins without signal peptides are not immediately secreted after translation and are not efficiently secreted. Rather, these proteins are normally secreted during the stationary phase (Yang et al., 2011). With the increase in research, more fine and category regulations have been reported.

\section{Modifications}

A small fraction of the glycolytic enzyme enolase is modified by its substrate 2-phosphoglycerate (2-PG). 2-PG is bound to Lys341 of Escherichia coli enolase or the equivalent of Lys341 in enolases of other bacteria. It has found that this enolase modification is a common phenomenon in bacteria, yeast and animals. More importantly, all Lys341 substitutions in $E$. coli enolase prevented not only the automodification, but also the export of enolase (Boël et al., 2004). This indicates that automodification is a prerequisite for the export of enolase, although it is unknown how the modification facilitates the export. To date, no other moonlighting proteins have been reported to need modification for its export in bacteria. In the eukarocyte, there are various modifications in these moonlighting proteins, but it is unknown whether these modifications are related to their transport (Capello et al., 2011; Prudovsky et al., 2013,). Further studies are needed to explore the relationship between modification and export.

\section{Induction}

It has been shown that growth conditions can affect the adherence of some Lactobacillus strains to components of the intestinal mucosa. For example, Lactobacillus gasseri and $L$. johnsonii strains showed stronger adhesion to laminin when grown in MRS agar under anaerobic conditions than in the same broth under aerobic conditions. Similarly, $L$. gasseri showed stronger adhesion to fibronectin in anaerobic conditions than aerobic conditions (Horie et al., 2005). Similarly, the secretion of moonlighting proteins is enhanced in certain conditions. The secretion of DnaK was enhanced in the presence of bile salts in Bifidobacterium animalis. The secretion of DnaK induced by bile salts is thought to facilitate the colonisation of the human host $B$. animalis in the gut bile environment (Candela et al., 2010). In the presence of a low level of glucose, L. plantarum exhibits an elevated level of cell wall-associated GAPDH (Saad et al., 2009). Similarly, Listeria adhesion protein expression in $L$. monocytogenes is enhanced in oxygen- and nutrientlimited conditions, and elevated temperatures (Koo et al., 2012). Additionally under iron starvation conditions, an increase in GAPDH release was seen in S. pyogenes and Streptococcus gordonii (Eichenbaum et al., 1996; Nelson et al., 2001). These conditions are generally believed to be the environments in which these bacteria survive. It seems that adhesion to intestinal mucosa is enhanced when experimental conditions mimic the human GIT environment. Moreover, these conditions can induce the secretion of moonlighting proteins with adhesion abilities.

\section{pH dependent localisation}

It seems that the export of moonlighting proteins on its own is not enough; these proteins must also locate suitable positions to exercise their moonlighting functions. For instance, surface-associated enolase and GAPDH in probiotics and pathogens have been reported to be reversible and $\mathrm{pH}$ dependent (Nelson et al., 2001; Antikainen et al., 2007b). These enzymes are attached to the cell surface in an acid $\mathrm{pH}$, but are released into the medium in a neutral or alkaline $\mathrm{pH}$. Similar to enolase and GAPDH, the binding of EF-Tu from $L$. johnsonii to intestinal cells and to mucins is $\mathrm{pH}$ dependent (Granato et al., 2004). This $\mathrm{pH}$ dependency for the attachment/release of surface-associated moonlighting proteins is likely to affect bacteria adhesion. The acidic $\mathrm{pH}$ of the intestinal mucosa will facilitate the adhesion of these proteins to the bacterial surface, thereby favouring the adhesion of bacteria to intestinal mucosa. When encountering an environment with a neutral or slightly alkaline $\mathrm{pH}$, a rapid detachment will occur. This could be one of the regulation strategies by which bacteria respond to physicochemical changes.

\section{Conclusions and future directions}

From this overview, it should be clear that major identified moonlighting functions of proteins in bacteria are adhesion to host epithelia, host components, such as extracellular matrices (ECMs) and plasminogen, and the modulation of host immune responses. Notably, moonlighting proteins share functional similarities in different bacteria, and these proteins play important roles in the bacteria's physiological activities. Their secretion and localisation are tightly regulated and induced by specific stimuli. However, there are many interesting questions that require further investigation into non-classically secreted proteins. How are moonlighting proteins exported and how does the modification affect this process? How do moomlighting protien's structures support so many different functions? Can the probiotic bacteria expressing the moonlighting proteins that function in host epithelia adhesion in pathogens competitively exclude and displace this provider? Can probiotic bacteria exchange moonlighting proteins, such as GAPDH and enolase, with the pathogens since these proteins exercise similar functions in both intracellular and extracellular bacteria types?

We hope that this review raises more research interest in tackling these and other related questions. A greater 
understanding of moonlighting proteins will be crucial in combating human pathogens.

\section{Acknowledgements}

This work was supported by the National Science Fund for Distinguished Young Scholars (31125021), the National Natural Science Foundation of China (No. 31171636, No. 21276108, No. 31000752), the National High Technology Research and Development Program of China (2011AA100905), the National Basic Research Program of China 973 Program (2012CB720802), the 111 project B07029, and the Fundamental Research Funds for the Central Universities (No. JUSRP51320B).

\section{References}

Agarwal, S., Kulshreshtha, P., Bambah Mukku, D., and Bhatnagar, R. (2008). alpha-Enolase binds to human plasminogen on the surface of Bacillus anthracis. Biochim. Biophys. Acta 1784, 986-994.

Aguilera, L., Giménez, R., Badia, J., Aguilar, J., and Baldoma, L. (2009). NAD ${ }^{+}$-dependent post-translational modification of Escherichia coli glyceraldehyde-3phosphate dehydrogenase. Int. Microbiol. 12, 187-192.

Alvarez, R.A., Blaylock, M.W., and Baseman, J.B. (2003). Surface localized glyceraldehyde-3-phosphate dehydrogenase of Mycoplasma genitalium binds mucin. Mol. Microbiol. 48, 1417-1425.

Antikainen, J., Kuparinen, V., Lähteenmäki, K., and Korhonen, T.K. (2007a). Enolases from Gram-positive bacterial pathogens and commensal lactobacilli share functional similarity in virulence-associated traits. FEMS Immunol. Med. Microbiol. 51, 526-534.

Antikainen, J., Kuparinen, V., Lähteenmäki, K., and Korhonen, T.K. (2007b). pH Dependent association of enolase and glyceraldehyde-3-phosphate dehydrogenase of Lactobacillus crispatus with the cell wall and lipoteichoic acids. J. Bacteriol. 189, 4539-4543.

Balasubramanian, S., Kannan, T.R., and Baseman, J.B. (2008). The surface-exposed carboxyl region of Mycoplasma pneumoniae elongation factor Tu interacts with fibronectin. Infect Immun. 76, 3116-3123.

Bergmann, S., Rohde, M., Chhatwal, G.S., and Hammerschmidt, S. (2001). alpha-Enolase of Streptococcus pneumoniae is a plasmin(ogen)-binding protein displayed on the bacterial cell surface. Mol. Microbiol. 40, 1273-1287.

Bergmann, S., Wild, D., Diekmann, O., Frank, R., Bracht, D., Chhatwal, G.S., and Hammerschmidt, S. (2003). Identification of a novel plasmin(ogen)-binding motif in surface displayed alpha-enolase of Streptococcus pneumoniae. Mol. Microbiol. 49, 411-423.

Bergmann, S., Rohde, M., and Hammerschmidt, S. (2004). Glyceraldehyde-3-phosphate dehydrogenase of Streptococcus pneumoniae is a surface-displayed plasminogen-binding protein. Infect Immun. 72, 24162419.

Bergmann, S., Rohde, M., Preissner, K.T., and Hammerschmidt, S. (2005). The nine residue plasminogenbinding motif of the pneumococcal enolase is the major cofactor of plasmin-mediated degradation of extracellular matrix, dissolution of fibrin and transmigration. Thromb. Haemost. 94, 304-311.

Bergonzelli, G.E., Granato, D., Pridmore, R.D., Marvin-Guy,
L.F., Donnicola, D., and Corthésy-Theulaz, I.E. (2006). GroEL of Lactobacillus johnsonii La1 (NCC 533) is cell surface associated: potential role in interactions with the host and the gastric pathogen Helicobacter pylori. Infect Immun. 74, 425-434.

Blau, K., Portnoi, M., Shagan, M., Kaganovich, A., Rom, S., Kafka, D., Chalifa Caspi, V., Porgador, A., Givon-Lavi, N., Gershoni, J.M., Dagan, R., and Mizrachi Nebenzahl, Y. (2007). Flamingo cadherin: a putative host receptor for Streptococcus pneumoniae. J. Infect Dis. 195, 18281837.

Boël, G., Pichereau, V., Mijakovic, I., Mazé, A., Poncet, S., Gillet, S., Giard, J.C., Hartke, A., Auffray, Y., and Deutscher, J. (2004). Is 2-phosphoglycerate-dependent automodification of bacterial enolases implicated in their export? J. Mol. Biol. 337, 485-496.

Boël, G., Jin, H., and Pancholi, V. (2005). Inhibition of cell surface export of group A streptococcal anchorless surface dehydrogenase affects bacterial adherence and antiphagocytic properties. Infect Immun. 73, 6237-6248.

Burnham, C.A., Shokoples, S.E., and Tyrrell, G.J. (2005). Phosphoglycerate kinase inhibits epithelial cell invasion by group B streptococci. Microb. Pathog. 38, 189-200.

Campbell, R.M., and Scanes, C.G. (1995). Endocrine peptides 'moonlighting' as immune modulators: roles for somatostatin and $\mathrm{GH}$-releasing factor. J. Endocrinol. 147, 383-396.

Candela, M., Centanni, M., Fiori, J., Biagi, E., Turroni, S., Orrico, C., Bergmann, S., Hammerschmidt, S., and Brigidi, P. (2010). DnaK from Bifidobacterium animalis subsp. lactis is a surface-exposed human plasminogen receptor upregulated in response to bile salts. Microbiology 156, 1609-1618

Capello, M., Ferri-Borgogno, S., Cappello, P., and Novelli, F. (2011). $\alpha$-Enolase: a promising therapeutic and diagnostic tumor target. FEBS J. 278, 1064-1074.

Cario, E., and Podolsky, D.K. (2006). Toll-like receptor signaling and its relevance to intestinal inflammation. Ann. N. Y. Acad. Sci. 1072, 332-338.

Carneiro, C.R., Postol, E., Nomizo, R., Reis, L.F., and Brentani, R.R. (2004). Identification of enolase as a laminin-binding protein on the surface of Staphylococcus aureus. Microbes Infect 6, 604-608.

Castaldo, C., Vastano, V., Siciliano, R.A., Candela, M., Vici, M., Muscariello, L., Marasco, R., and Sacco, M. (2009). Surface displaced alfa-enolase of Lactobacillus plantarum is a fibronectin binding protein. Microb. Cell Fact. 8, 14.

Collado, M.C., Gueimonde, M., Hernandez, M., Sanz, Y., and Salminen, S. (2005). Adhesion of selected Bifidobacterium strains to human intestinal mucus and the role of adhesion in enteropathogen exclusion. J. Food Prot. 68, 2672-2678.

Cork, A.J., Jergic, S., Hammerschmidt, S., Kobe, B., Pancholi, V., Benesch, J.L., Robinson, C.V., Dixon, N.E., Aquilina, J.A., and Walker, M.J. (2009). Defining the structural basis of human plasminogen binding by streptococcal surface enolase. J. Biol. Chem. 284, 1712917137.

Dallo, S.F., Kannan, T.R., Blaylock, M.W., and Baseman, J.B. (2002). Elongation factor Tu and E1 b subunit of pyruvate dehydrogenase complex act as fibronectin binding proteins in Mycoplasma pneumoniae. Mol. Microbiol. 46, 1041-1051. 
D'Costa, S.S., and Boyle, M.D. (2000). Interaction of group A streptococci with human plasmin(ogen) under physiological conditions. Methods 21, 165-177.

Derbise, A., Song, Y.P., Parikh, S., Fischetti, V.A., and Pancholi, V. (2004). Role of the C-terminal lysine residues of streptococcal surface enolase in Glu- and Lysplasminogen-binding activities of group A streptococci. Infect Immun. 72, 94-105.

Eberhard, T., Kronvall, G., and Ullberg, M. (1999). Surface bound plasmin promotes migration of Streptococcus pneumoniae through reconstituted basement membranes. Microb. Pathog. 26, 175-181.

Egea, L., Aguilera, L., Giménez, R., Sorolla, M.A., Aguilar, J., Badía, J., and Baldoma, L. (2007). Role of secreted glyceraldehyde-3-phosphate dehydrogenase in the infection mechanism of enterohemorrhagic and enteropathogenic Escherichia coli: interaction of the extracellular enzyme with human plasminogen and fibrinogen. Int. J. Biochem. Cell Biol. 39, 1190-1203.

Ehinger, S., Schubert, W.D., Bergmann, S., Hammerschmidt, S., and Heinz, D.W. (2004). Plasmin(ogen)-binding alpha-enolase from Streptococcus pneumoniae: crystal structure and evaluation of plasmin(ogen)-binding sites. J. Mol. Biol. 343, 997-1005.

Eichenbaum, Z., Green, B.D., and Scott, J.R. (1996). Iron starvation causes release from the group A streptococcus of the ADP-ribosylating protein called plasmin receptor or surface glyceraldehyde-3-phosphate-dehydrogenase. Infect Immun. 64, 1956-1960.

Fontan, P.A., Pancholi, V., Nociari, M.M., and Fischetti, V.A. (2000). Antibodies to streptococcal surface enolase react with human alpha-enolase: implications in poststreptococcal sequelae. J. Infect Dis. 182, 17121721.

Ge, J., Catt, D.M., and Gregory, R.L. (2004). Streptococcus mutans surface alpha-enolase binds salivary mucin MG2 and human plasminogen. Infect Immun. 72, 6748-6752.

Granato, D., Bergonzelli, G.E., Pridmore, R.D., Marvin, L., Rouvet, M., and Corthesy-Theulaz, I.E. (2004). Cell surface-associated elongation factor Tu mediates the attachment of Lactobacillus johnsonii NCC533 (La1) to human intestinal cells and mucins. Infect Immun. 72, 2160-2169.

Gueimonde, M., Margolles, A., de los Reyes-Gavilán, C.G., and Salminen, S. (2007). Competitive exclusion of enteropathogens from human intestinal mucus by Bifidobacterium strains with acquired resistance to bile-a preliminary study. Int. J. Food Microbiol. 113, 228-232.

Heinemann, C., van Hylckama Vlieg, J.E., Janssen, D.B., Busscher, H.J., van der Mei, H.C., and Reid, G. (2006). Purification and characterization of a surface-binding protein from Lactobacillus fermentum RC-14 that inhibits adhesion of Enterococcus faecalis 1131. FEMS Microbiol. Lett. 190, 177-180.

Henderson, B., and Martin, A. (2011). Bacterial virulence in the moonlight: multitasking bacterial moonlighting proteins are virulence determinants in infectious disease. Infect Immun. 79, 3476-3491.

Horie, M., Murakami, T., Sato, T., Tarusawa, Y., Nakamura, S., and Toba, T. (2005). Anaerobic induction of adherence to laminin in Lactobacillus gasseri strains by contact with solid surface. Curr. Microbiol. 51, 275-282.

Huberts, D.H., and van der Klei, I.J. (2010). Moonlighting proteins: an intriguing mode of multitasking. Biochim. Biophys. Acta 1803, 520-525.

Hurmalainen, V., Edelman, S., Antikainen, J., Baumann, M., Lähteenmäki, K., and Korhonen, T.K. (2007). Extracellular proteins of Lacobacillus crispatus enhance activation of human plasminogen. Microbiology 153, 1112-1122.

Jagadeesan, B., Koo, O.K., Kim, K.P., Burkholder, K.M., Mishra, K.K., Aroonnual, A., and Bhunia, A.K. (2010). $\mathrm{LAP}$, an alcohol acetaldehyde dehydrogenase enzyme in Listeria, promotes bacterial adhesion to enterocyte-like Caco-2 cells only in pathogenic species. Microbiology 156, 2782-2795.

Jeffery, C.J. (2009). Moonlighting proteins-an update. Mol. Biosyst. 5, 345-350.

Jin, H., Song, Y.P., Boel, G., Kochar, J., and Pancholi, V. (2005). Group A streptococcal surface GAPDH, SDH, recognizes UPAR/CD87 as its receptor on the human pharyngeal cell and mediates bacterial adherence to host cells. J. Mol. Biol. 350, 27-41.

Jin, H., Agarwal, S., Agarwal, S., and Pancholi, V. (2011). Surface export of GAPDH/SDH, a glycolytic enzyme, is essential for Streptococcus pyogenes virulence. MBio 2, e00068-11.

Kainulainen, V., Loimaranta, V., Pekkala, A., Edelman, S., Antikainen, J., Kylväjä, R., Laaksonen, M., Laakkonen, L., Finne, J., and Korhonen, T.K. (2012). Glutamine synthetase and glucose-6-phosphate isomerase are adhesive moonlighting proteins of Lactobacillus crispatus released by epithelial cathelicidin LL-37. J. Bacteriol. 194, 2509-2519.

Kelly, P., Maguire, P.B., Bennett, M., Fitzgerald, D.J., Edwards, R.J., Thiede, B., Treumann, A., Collins, J.K., O'Sullivan, G.C., Shanahan, F., and Dunne, C. (2005). Correlation of probiotic Lactobacillus salivarius growth phase with its cell wall-associated proteome. FEMS Microbiol. Lett. 252, 153-159.

Khan, I.K., Chitale, M., Rayon, C., and Kihara, D. (2012). Evaluation of function predictions by PFP, ESG, and PSIBLAST for moonlighting proteins. BMC Proc. 6 Suppl 7:S5.

Kinhikar, A.G., Vargas, D., Li, H., Mahaffey, S.B., Hinds, L., Belisle, J.T., and Laal, S. (2006). Mycobacterium tuberculosis malate synthase is a laminin-binding adhesin. Mol. Microbiol. 60, 999-1013.

Kinoshita, H., Uchida, H., Kawai, Y., Kawasaki, T., Wakahara, N., Matsuo, H., Watanabe, M., Kitazawa, H., Ohnuma, S., Miura, K., Horii, A., and Saito, T. (2008). Cell surface Lactobacillus plantarum LA 318 glyceraldehyde3-phosphate dehydrogenase (GAPDH) adheres to human colonic mucin. J. Appl. Microbiol. 104, 1667-1674.

Koo, O.K., Amalaradjou, M.A.R., and Bhunia, A.K. (2012). Recombinant probiotic expressing Listeria adhesion protein attenuates Listeria monocytogenes virulence in vitro. PLoS one 7, e29277.

Lähteenmäki, K., Edelman, S., and Korhonen, T.K. (2005). Bacterial metastasis: the host plasminogen system in bacterial invasion. Trends Microbiol. 13, 79-85.

Ling, E., Feldman, G., Portnoi, M., Dagan, R., Overweg, K., Mulholland, F., Chalifa-Caspi, V., Wells, J., and MizrachiNebenzahl, Y. (2004). Glycolytic enzymes associated with the cell surface of Streptococcus pneumoniae are antigenic in humans and elicit protective immune 
responses in the mouse. Clin. Exp. Immunol. 138, 290298.

Lundberg, K., Wegner, N., Yucel-Lindberg, T., Venables, P.J. (2010). Periodontitis in RA-the citrullinated enolase connection. Nat. Rev. Rheumatol. 6, 727-730.

Ma, D., Forsythe, P., and Bienenstock, J. (2004). Live Lactobacillus rhamnosus is essential for the inhibitory effect on tumor necrosis factor alpha-induced interleukin-8 expression. Infect Immun. 72, 5308-5314.

Madureira, P., Baptista, M., Vieira, M., Magalhães, V., Camelo, A., Oliveira, L., Ribeiro, A., Tavares, D., Trieu-Cuot, P., Vilanova, M., and Ferreira, P. (2007). Streptococcus agalactiae GAPDH is a virulenceassociated immunomodulatory protein. J. Immunol. 178, 1379-1387.

Matta, S.K., Agarwal, S., and Bhatnagar, R. (2010). Surface localized and extracellular Glyceraldehyde-3-phosphate dehydrogenase of Bacillus anthracis is a plasminogen binding protein. Biochim. Biophys. Acta 1804, 2111-2120.

Nakamura, J., Ito, D., Nagai, K., Umekara, Y., Hamachi, M., and Kumagai, C. (1997). Rapid and sensitive detection of hiochi bacteria by amplification of hiochi bacterial common antigen gene by PCR method and characterization of the antigen. J. Ferment. Bioeng. 83, 161-167.

Nelson, D., Goldstein, J.M., Boatright, K., Harty, D.W., Cook, S.L., Hickman, P.J., Potempa, J., Travis, J., Mayo, and J.A. (2001). pH-regulated secretion of a glyceraldehyde3-phosphate dehydrogenase from Streptococcus gordonii FSS2: purification, characterization, and cloning of the gene encoding this enzyme. J. Dent. Res. 80, 371-377.

Nilsson, J., and Nissen, P. (2005). Elongation factors on the ribosome. Curr. Opin. Struct. Biol. 15, 349-354.

Pancholi, V., and Fischetti, V.A. (1992). A major surface protein on group A streptococci is a glyceraldehyde3-phosphate-desydrogenase with multiple binding activity. J. Exp. Med. 176, 415-426.

Pancholi, V., and Fischetti, V.A. (1998). a-Enolase, a novel strong plasmin(ogen) binding protein on the surface of pathogenic streptococci. J. Biol. Chem. 273, 1450314515.

Pancholi, V., and Chhatwal, G.S. (2003). Housekeeping enzymes as virulence factors for pathogens. Int. J. Med. Microbiol. 293, 391- 401.

Prudovsky, I., Kumar, T.K., Sterling, S., and Neivandt, D. (2013). Protein-phospholipid interactions in nonclassical protein secretion: problem and methods of study. Int. J. Mol. Sci. 14, 3734-3772.

Ramiah, K., van Reenen, C.A., and Dicks, L.M. (2008). Surface-bound proteins of Lactobacillus plantarum 423 that contribute to adhesion of Caco-2 cells and their role in competitive exclusion and displacement of Clostridium sporogenes and Enterococcus faecalis. Res. Microbiol. 159, 470-475.

Reddy, V.M., and Suleman, F.G. (2004). Mycobacterium avium-superoxide dismutase binds to epithelial cell aldolase, glyceraldehyde-3-phosphate dehydrogenase and cyclophilin A. Microb. Pathog. 36, 67-74.

Saad, N., Urdaci, M., Vignoles, C., Chaignepain, S., Tallon, R., Schmitter, J.M., and Bressollier, P. (2009). Lactobacillus plantarum 299v surface-bound GAPDH: a new insight into enzyme cell walls location. J. Microbiol. Biotechnol. 19, 1635-1643.

Sánchez, B., Bressollier, P., and Urdaci, M.C. (2008). Exported proteins in probiotic bacteria: adhesion to intestinal surfaces, host immunomodulation and molecular cross-talking with the host. FEMS Immunol. Med. Microbiol. 54, 1-17.

Sanderson-Smith, M.L., Walker, M.J., and Ranson, M. (2006). The maintenance of high affinity plasminogen binding by group A streptococcal plasminogen-binding M-like protein is mediated by arginine and histidine residues within the $\mathrm{a} 1$ and $\mathrm{a} 2$ repeat domains. J. Biol. Chem. 281, 25965-25971.

Sanderson-Smith, M.L., Dowton, M., Ranson, M., and Walker, M.J. (2007). The plasminogen-binding group A streptococcal $M$ protein-related protein Prp binds plasminogen via arginine and histidine residues. J. Bacteriol. 189, 1435-1440.

Seifert, K.N., McArthur, W.P., Bleiweis, A.S., and Brady, L.J. (2003). Characterization of group B streptococcal glyceraldehyde-3-phosphate dehydrogenase: surface localization, enzymatic activity, and protein-protein interactions. Can. J. Microbiol. 49, 350-356.

Siciliano, R.A., Cacace, G., Mazzeo, M.F., Morelli, L., Elli, M., Rossi, M., and Malorni, A. (2008). Proteomic investigation of the aggregation phenomenon in Lactobacillus crispatus. Biochim. Biophys. Acta 1784, 335-342.

Spurbeck, R.R., and Arvidson, C.G. (2010). Lactobacillus jensenii surface associated proteins inhibit Neisseria gonorrhoeae adherence to epithelial cells. Infect Immun. 78, 3103-3111.

Terao, Y., Yamaguchi, M., Hamada, S., and Kawabata, S. (2006). Multifunctional glyceraldehyde-3-phosphate dehydrogenase of Streptococcus pyogenes is essential for evasion from neutrophils. J. Biol. Chem. 281, 1421514223.

Winram, S.B., and Lottenberg, R. (1996). The plasminbinding protein Plr of group A streptococci is identified as glyceraldehyde-3-phosphate dehydrogenase. Microbiology 142, 2311-2320.

Xolalpa, W., Vallecillo, A.J., Lara, M., Mendoza-Hernandez, G., Comini, M., Spallek, R., Singh, M., and Espitia, C. (2007). Identification of novel bacterial plasminogen binding proteins in the human pathogen Mycobacterium tuberculosis. Proteomics 7, 3332-3341.

Yang, C.K., Ewis, H.E., Zhang, X., Lu, C.D., Hu, H.J., Pan, Y., Abdelal, A.T., and Tai, P.C. (2011). Nonclassical protein secretion by Bacillus subtilis in the stationary phase is not due to cell lysis. J. Bacteriol. 193, 5607-5615. 


\section{Further Reading}

Caister Academic Press is a leading academic publisher of advanced texts in microbiology, molecular biology and medical research. Full details of all our publications at caister.com

- MALDI-TOF Mass Spectrometry in Microbiology Edited by: M Kostrzewa, S Schubert (2016) www.caister.com/malditof

- Aspergillus and Penicillium in the Post-genomic Era Edited by: RP Vries, IB Gelber, MR Andersen (2016) www.caister.com/aspergillus2

- The Bacteriocins: Current Knowledge and Future Prospects Edited by: RL Dorit, SM Roy, MA Riley (2016)

www.caister.com/bacteriocins

- Omics in Plant Disease Resistance Edited by: V Bhadauria (2016) www.caister.com/opd

- Acidophiles: Life in Extremely Acidic Environments Edited by: R Quatrini, DB Johnson (2016) www.caister.com/acidophiles

- Climate Change and Microbial Ecology: Current Research and Future Trend

Edited by: J Marxsen (2016)

www.caister.com/climate

- Biofilms in Bioremediation: Current Research and Emerging Technologies

Edited by: G Lear (2016)

www.caister.com/biorem

- Microalgae: Current Research and Applications Edited by: MN Tsaloglou (2016) www.caister.com/microalgae

- Gas Plasma Sterilization in Microbiology: Theory, Applications, Pitfalls and New Perspectives Edited by: H Shintani, A Sakudo (2016) www.caister.com/gasplasma

- Virus Evolution: Current Research and Future Directions Edited by: SC Weaver, M Denison, M Roossinck, et al. (2016) www.caister.com/virusevol

- Arboviruses: Molecular Biology, Evolution and Control Edited by: N Vasilakis, DJ Gubler (2016) www.caister.com/arbo

- Shigella: Molecular and Cellular Biology Edited by: WD Picking, WL Picking (2016) www.caister.com/shigella

-Aquatic Biofilms: Ecology, Water Quality and Wastewater Treatment

Edited by: AM Romaní, H Guasch, MD Balaguer (2016)

www.caister.com/aquaticbiofilms

- Alphaviruses: Current Biology

Edited by: S Mahalingam, L Herrero, B Herring (2016)

www.caister.com/alpha

- Thermophilic Microorganisms

Edited by: F Li (2015)

www.caister.com/thermophile
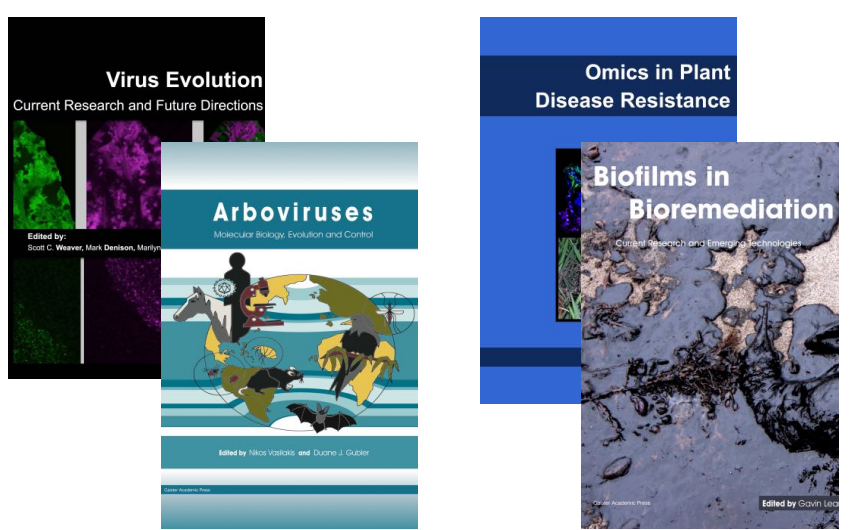
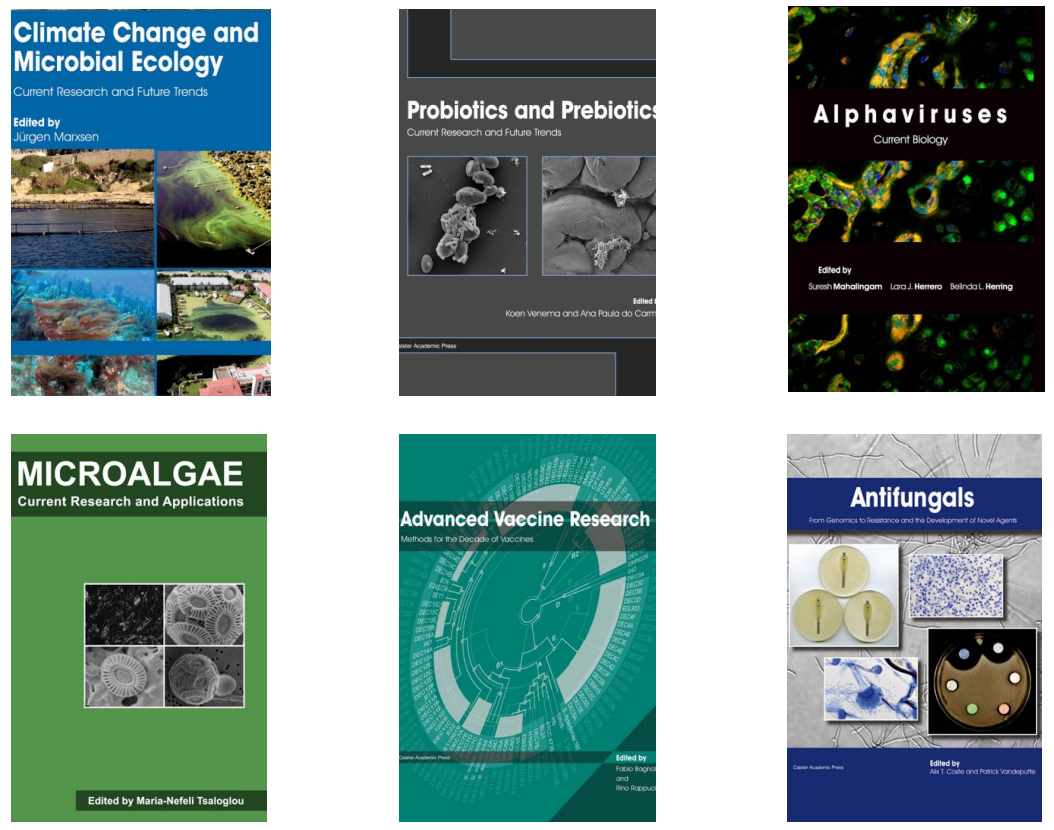

- Flow Cytometry in Microbiology: Technology and Applications Edited by: MG Wilkinson (2015) www.caister.com/flow

- Probiotics and Prebiotics: Current Research and Future Trends Edited by: K Venema, AP Carmo (2015) www.caister.com/probiotics

- Epigenetics: Current Research and Emerging Trends Edited by: BP Chadwick (2015) www.caister.com/epigenetics2015

- Corynebacterium glutamicum: From Systems Biology to Biotechnological Applications

Edited by: A Burkovski (2015)

www.caister.com/cory2

- Advanced Vaccine Research Methods for the Decade of Vaccines

Edited by: F Bagnoli, R Rappuoli (2015)

www.caister.com/vaccines

- Antifungals: From Genomics to Resistance and the Development of Novel Agents

Edited by: AT Coste, P Vandeputte (2015)

www.caister.com/antifungals

- Bacteria-Plant Interactions: Advanced Research and Future Trends Edited by: J Murillo, BA Vinatzer, RW Jackson, et al. (2015) www.caister.com/bacteria-plant

\section{- Aeromonas}

Edited by: J Graf (2015)

www.caister.com/aeromonas

- Antibiotics: Current Innovations and Future Trends

Edited by: S Sánchez, AL Demain (2015)

www.caister.com/antibiotics

- Leishmania: Current Biology and Contro Edited by: S Adak, R Datta (2015) www.caister.com/leish2

- Acanthamoeba: Biology and Pathogenesis (2nd edition) Author: NA Khan (2015)

www.caister.com/acanthamoeba2

- Microarrays: Current Technology, Innovations and Applications Edited by: Z He (2014)

www.caister.com/microarrays2

- Metagenomics of the Microbial Nitrogen Cycle: Theory, Methods and Applications

Edited by: D Marco (2014)

www.caister.com/n2 